\title{
AVALIAÇÃO DE MÉTODO DE CONTROLE DO ESCOAMENTO SUPERFICIAL PARA A DRENAGEM URBANA SUSTENTÁVEL NA BACIA DO RIO ITAPOCU/SC
}

\author{
ADILSON GORNIACK, M.SC. | UDESC \\ MARIA PAULA CASAGRANDE MARIMON, Dra. | UDESC
}

\section{INTRODUÇÃO}

Acorrentados ao processo de urbanização estão à impermeabilização do solo, aterros, canalizações de cursos naturais de águas, desmatamento, entre outros, que geram significativas mudanças no escoamento das águas das chuvas. Uma das consequências da alteração do uso do solo é o aumento do potencial destrutivo e da frequência das inundações.

O objetivo principal dessa dissertação foi o analisar os princípios da Drenagem Urbana Sustentável (DUS), de sorte a propor um novo modus operandi na gestão do escoamento das águas pluviais na bacia do Itapocu que viesse a contribuir na harmonização do ambiente construído e o meio natural.

A fim de consolidar esse objetivo, três diretrizes foram propostas:

- verificar na legislação dos municípios inseridos na bacia hidrográfica do Rio Itapocu a aplicação da filosofia da DUS - controle na fonte - a existência da Taxa de Permeabilidade;

- propor um método para determinação da Taxa de Permeabilidade Mínima para a bacia do Rio Itapocu e

- estudar medidas compensatórias como forma de controlar o escoamento superficial no lote.

Considerando a natureza das diretrizes em que temas voltados à gestão (legislação) se misturam à vertente técnica (dimensionamento), o método empregado foi a revisão bibliográfica.

\section{RESULTADOS}

Ao estudar a aplicação dos princípios da DUS, controle na fonte, efetivados por áreas de infiltração no lote e regulamentados pela presença legal da taxa de permeabilidade na legislação dos municípios, verificou-se que dos 12 (doze) municípios da bacia do Rio Itapocu, apenas 03 (três) dispõem de tal instrumento urbanístico consolidado quantitativamente, a saber: Blumenau na taxa de permeabilidade de $20 \%$ (vinte por cento) e o seu complemento a taxa de impermeabilidade nos municípios de Campo Alegre e São Bento do Sul no percentual máximo de 10\% (dez) da taxa de ocupação. Estes dois últimos municípios apresentam percentuais maiores, uma vez que transformados em termos de taxa de permeabilidade resultam em 45\% (quarenta e cinco) para o município de Campo Alegre e 34\% (trinta e quatro) para o município de São Bento do Sul.

Interessante pontuar a legislação dos municípios de Joinville e Schroeder, em que a taxa de permeabilidade é conceituada, mas não estava devidamente quantificada, sendo elemento meramente figurativo.

A segunda diretriz foi alcançada com recursos advindos das engenharias, arquitetura e sociologia e teve como resultado a equação (1), a seguir:

TPM $(\%)=(\mathbf{f p}) \times($ IAV $) \times 100 /($ LPM $)$

Onde:

TPM - taxa de permeabilidade mínima

$f p$ - família padrão (IBGE- 4 habitantes).

IAV - índice de área verde - $(12,00 \mathrm{~m} 2 / \mathrm{hab})$

LPM-Lote Padrão Mínimo- (240,00m2).

A equação aplicada ao município de Joinville resultou na taxa de permeabilidade de $20 \%$ (artigo 64, da Lei Complementar $n^{\circ}$ 470/2017).

Para alcançar o objetivo principal (harmonizar o ambiente construído e o natural), a terceira diretriz - medidas compensatórias- inseriu um novo modus operandi na forma de controlar o escoamento superficial no município de Joinville, que veio a consolidar o conceito "jardins drenantes" (Artigo 2, Decreto no 33.767/2019).

\section{REFERÊNCIAS}

GORNIACK, Adilson. Avaliação de Método de Controle do Escoamento Superficial para Drenagem Urbana Sustentável na Bacia do Rio Itapocu - SC. Dissertação de Mestrado - MPPT/ UDESC. Florianópolis - SC, 2014 
